\title{
Legal considerations regarding a hypothetical unilateral declaration of independence by Catalonia: a legally unfeasible political scenario
}

\author{
José MARTÍN Y PÉREZ DE NANCLARES
}

\begin{abstract}
Catalonia cannot in any way be considered a subject in its own right with a purported 'right to decide' in the event of a hypothetical materialisation of a unilateral declaration of independence. And this cannot be so either on a domestic level or on an international one. Both the Spanish Constitution and international law directly oppose any type of secession by part of a territory of a State that, as is the case with Spain, is founded on the principles of democracy and the rule of law. States have a kind of duty to refrain from recognizing the aspiring State resulting from a unilateral declaration of this kind, as to do otherwise could be even interpreted as meddling in Spain's internal affairs. It appears beyond any legal doubt that the nascent State would be left out of all the international organizations of which Spain is a member, including, of course, the European Union. Quite another matter is clarifying whether, on a political level, attempts could be made to find Catalonia a new constitutional 'fit' within Spain that respected territorial unity and were reasonably satisfactory to all involved.
\end{abstract}

Keywords: Spain - Catalonia - Secession - Unilateral independence

\section{OVERVIEW}

The delicate political context in Catalonia after the elections to the Catalan parliament of the 27 September 2015 has rekindled the debate as to whether a scenario of a hypothetical unilateral declaration of independence would be legally viable. It is, therefore, worth taking the time to examine the specific legal framework within which any analysis of a such hypothetical unilateral declaration of independence by Catalonia should be conducted; and it is worth attempting to do so through what Pérez Royo, discussing this same issue, calls 'an honest legal debate'.

It is precisely for this reason that we must begin by highlighting two pre-existing issues that shape this study. Firstly, such a legal analysis must necessarily be shrouded in a certain amount of uncertainty, due to the fact that the political scenario in question is based on mere speculation-a scenario whose precise ins and outs are (obviously) unknown, and for which the possible variables and potential outcomes are uncertain. What this analysis must actually be based on is a working hypothesis that, in order to somehow anchor the study with a minimal degree of firmness, assumes a potential unilateral declaration of independence by Catalonia. ${ }^{2}$ For analytical purposes, the unlikely

Professor of Public International Law, University of Salamanca. Head of the International Legal Office, Spanish Ministry of Foreign Affairs and Cooperation. The opinions expressed in this paper are the author's own, and cannot be attributed in any way to the institution at which he is currently employed.

I J. Pérez Royo, 'Entre política y Derecho: el debate sobre la independencia de Cataluña', in La autodeterminación a debate, ed. by J. Solozábal Echevarría (Madrid: Pablo Iglesias, 2014), pp. 143-155, (p. 147).

2 In practice, this is not actually such a hypothetical scenario, as both the Generalitat (regional government) of Catalonia and the National Transition Council (the advisory body that the Generalitat has set up to support the intended independence process), provide sufficient examples of the possible scenario in several documents. The most important of these is the white paper entitled Libro Blanco - La transición nacional de Cataluña (Barcelona, 20I4), particularly pp. 36-40 
scenario of a separation of Catalonia from the Kingdom of Spain based on an express agreement between the parties can, therefore, be dispensed with; logically, in such a case the resulting legal framework would be the one agreed upon by both parties, and a good many of the statements expressed below would not be applicable. S Similarly, the scenario in question is considered here to affect Catalonia and Catalonia alone, since, if more than one of Spain's Autonomous Communities were to embark on a process of this kind, perhaps some of our conclusions would also need a certain amount of qualification. ${ }^{4}$ Therefore, we find ourselves before the most complex of imaginable scenarios: a hypothetical declaration of independence made unilaterally, disregarding the (political, constitutional and legal) will of the State of which the territory forms part. However, we could also find ourselves faced with a sort of unilateral 'declaration of successive lapse of time' (declaración unilateral de independencia de tracto sucesivo). As the Resolution of the Parliament of Catalonia of 9 November 2015 establishes, the Parliament solemnly declares "the beginning of the process to create an independent Catalan State in the form of a republic" (point 2) und "urges the future government to adopt the necessary measures to give effect to these declarations" (point 4).5

Secondly, we cannot ignore the fact that this complex and delicate issue is liable to be assessed from a very wide range of different perspectives (political, economic, monetary, sociological, etc.), each

(on the "Third stage of the creation of the new Catalan State: From the proclamation or unilateral declaration of independence to the passing of a Constitution'). Other documents of interest are the 19 reports that the National Transition Council has published on different issues such as consultation (report number I), tax authorities (number 2), cooperation relations with Spain (number 3), internationalizing the self-determination process (number 4), communications (number 5), ways of integration into the EU (number 6), distribution of assets and liabilities (number 7), monetary issues (numbers 7 and 8), water and energy supply (number 9), the constitution-making process (number 10), trade relations with Spain (number II), administrative structures (number I2), integration into the international community (number I3), the judiciary (number 14), social security (number 15), the succession of the legal system (number 16), internal and external security (number 17), fiscal viability (number 18 ) and a final overview of the entire process (number 19). All of these reports are available on the website of the Generalitat (http://presidencia.gencat.cat). Specific reference to external action and the creation of State structures abroad can also be found in Pla stratègic d'acció exterior i de relacions amb la Unió Europea 20I52018 (5I pages).

3 If this were the case, an agreement would be negotiated between the nascent State and Spain, establishing the precise terms of the succession. This would, for example, have been the foreseeable legal scenario had the referendum held in Scotland on I8 September 2014 resulted in a victory for the 'yes' campaign and, with it, the negotiation of the terms of formation of the new State.

4 When a State breaks up, what actually happens is that two or more new States emerge from the former State, although this theory also assumes that the terms of the formation of the new States would be negotiated in an agreement between the parties concerned. The breakup of the former Czechoslovakia into the Czech Republic and Slovakia (I January 1993) can be included in this category. As a mere laboratory hypothesis' we could also consider the case of Belgium, in the event that the existing State were broken up to form two new -Flemish and Walloon- States; remember, in this regard, that Article 7 of the Belgian Constitution provides that the limits of the State can be amended by an Act of Parliament.

5 Resolution I/XI of the Parliament of Catalonia of 9 November 20I5, on the beginning of the political process in Catalonia arising from the election results of 27 September 2015 (Boletin Oficial del Parlamento de Cataluña no. 7, of 9 November 2015). Regarding the 'process', the Resolution also "reiterates that this Chamber [the Catalan Parliament] and the process of democratic uncoupling from the Spanish State shall not be subject to the decisions of the institutions of the Spanish State, in particular the Constitutional Court, which it considers devoid of legitimacy and jurisdiction (...)" (point 6) and, at the same time, "the Parliament of Catalonia shall adopt the measures necessary to open this process of uncoupling from the Spanish State (...) making it possible to empower the citizen at every level, and on the basis of open, active, and inclusive participation" (point 7). The Spanish Government challenged the Resolution and the Spanish Constitutional Court unanimously declared the said Resolution "to be unconstitutional, null and void"; CC judgment 259/2015, of 2 December 2015. 
of them having multiple variations. Nevertheless, as far as possible, this paper will attempt to focus solely and exclusively on aspects of a legal nature, notwithstanding that even a legal analysis accepts different approaches, as the different elements of both domestic and international law are interlinked. In this respect, it is the author's intention to limit this analysis to matters of international law and European Union law, although the substantive content of international legislation does require some brief initial references to domestic law. On this basis, this paper will conclude with some short closing remarks.

\section{THE DOMESTIC LEGAL FRAMEWORK: NON-EXISTENCE OF A RIGHT OF SECESSION}

(I) The non-existence of a right of secession in comparative law: Constitutional reform is required first

The occasional minor exception - such as Ethiopia ${ }^{6}$ or the tiny archipelago of Saint Kitts and Nevis $^{7}$ - notwithstanding, none of the world's constitutions currently recognizes the right of secession of part of a State's territory. This is not even the case of the constitutions of the most highly decentralized federal States. In fact, there is consensus that even the idiosyncratic provisions of the Canadian ${ }^{8}$ and South African ${ }^{9}$ constitutions are not in any way equivalent to a right of secession. The situation is quite the opposite, in fact: constitutions usually make express reference to the State's territorial integrity or indivisibility. ${ }^{10}$

Even the most cursory of glances at the history of constitutional law brings us to the conclusion that only Soviet-bloc constitutions ever contained such provisions, this being the case of the constitutions of the USSR, ${ }^{\mathrm{II}}$ Yugoslavia ${ }^{\mathrm{I} 2}$ and, finally, Czechoslovakia. ${ }^{\mathrm{I}}$ Looking beyond Europe we can cite the Burmese constitution, which initially included such a provision but later expressly repealed it. ${ }^{\mathrm{I}}$ Even so, it is obvious that these provisions belong more to the rhetorical sphere than to the real world. ${ }^{15}$

6 Article 39.r of the 1994 Constitution.

Section 115 of the 1983 Constitution.

8 This is corroborated by the opinion of the Supreme Court of 20 August 1998; 2 Supreme Court Reporter (SCR) 217.

9 Section 235 of the 1996 Constitution.

ro See, for example, Article 2 of the Austrian Constitution. See also Section 3 of the Finnish Constitution, Article 5.I of the Italian Constitution, Article 3.I of the Portuguese Constitution and Article I of the French Constitution of 1958 ('La France est une République indivisible...'). In this last case, the reference to the indivisibility of the State can be traced back throughout France's constitutional history (Article I of the 1946 Constitution, Section II of the preamble to the 1848 Constitution, and Article I of the 1799, I795, 1793 and 179r Constitutions).

" Articles 70 and 72 of the repealed USSR Constitution, which, nevertheless, contained no procedural rules for making such a pronouncement.

${ }_{12}$ Article I of the 1974 Yugoslav Constitution.

13 Constitutional reform of 1990.

${ }^{14}$ Introduced by Article 20I of the 1947 Constitution and later repealed in 1974.

is These provisions were probably an attempt to maintain coherence with Lenin's doctrine on self-determination, whereby 'the right of nations to self-determination implies exclusively the right to independence in the political sense, the right to free political separation from the oppressor nation. Specifically, this demand for political democracy implies complete freedom to agitate for secession and for a referendum for secession by the seceding nation'; V. I. Lenin, Collected Works (Moscow: Progress Publishers, 1964), p. 146. 
Moreover, the highest courts of those federal States with the greatest degree of territorial decentralization have categorically rebuffed all secessionist aspirations. The United States Supreme Court has not, therefore, altered the stance it adopted in the case of Texas $v$. White (I868), when it ruled the Southern States' secession to be unconstitutional. ${ }^{16}$ In this context, in response to a people's petition of 9 November 2012, in which I25,746 individuals requested that the government 'peacefully grant the State of Texas to withdraw from the United States of America and create its own new government', the response from the White House, in a missive published on its own website and signed by John Carson, Director of the White House's Office of Public Engagement, was that the founding fathers of the US Constitution 'did not provide a right to walk away' and that 'the Union of these States is perpetual'. In fact, seven other similar petitions (concerning Alabama, Florida, Georgia, Louisiana, North Carolina, South Carolina, and Tennessee) have received the same response. Even the Supreme Court of Canada's oft-cited statement of 20 August 1998 made it very clear that the secession of Quebec would only be viable if the federal Constitution were reformed first. ${ }^{17}$

In this same vein, it should, finally, be noted that federal constitutions usually contain 'federal coercion' mechanisms for dealing with serious breaches of federal law by the federate units. We can probably cite as a prototype the Bundeszwang mechanism provided for in the Basic Law of Bonn. ${ }^{18}$ This is actually an instrument aimed at the effective enforcement of the core principle of federal loyalty (Bundestreue) and, more than a mechanism of commonplace use, acts as a deterrent to ensure the Länder's compliance with the law of the Federation. ${ }^{19}$

(2) The non-existence of any right of secession in the 1978 Spanish Constitution: Legal mechanisms guaranteeing observance of the Constitution

The non-existence of any right of secession by part of Spain can also be inferred from the Spanish Constitution of 1978. It does not allow part of the Spanish territory to unilaterally exercise a purported 'right to decide' that could lead to a similarly unilateral declaration of independence. This

16 74 US 700 (I869). The United States Supreme Court categorically states that the Constitution, in all its provisions, looks to an indestructible Union, composed of indestructible States. When, therefore, Texas became one of the United States, she entered into an indissoluble relation. (...) The union between Texas and the other States was as complete, as perpetual, and as indissoluble as the union between the original States'.

${ }_{17} 2$ Supreme Court Reporter (SCR) 217. See P. Dumberry, 'Lessons learned from the Quebec Secession Reference before the Supreme Court of Canada' in Secession. International Law Perspectives ed. by M. G. Kohen, (Cambridge: Cambridge University Press, 2006), pp. 416-45I.

i8 According to Article 37 of the Basic Law of Bonn: 'I. If a Land fails to comply with its obligations under this Basic Law or other federal laws, the Federal Government, with the consent of the Bundesrat [Federal Council], may take the necessary steps to compel the Land to comply with its duties through federal coercion. 2. For the purpose of implementing such coercive measures, the Federal Government or its representative shall have the right to issue instructions to all Länder and their authorities.'

19 As far as the author is aware, in Germany this mechanism has never been used in practice. The same cannot be said of other federal States. For example, the principle of federal coercion bas been used on occasions in the United States, even resorting to the use of force (the National Guard). The most notable case occurred in 1957, when President Eisenhower used this mechanism to counteract the State of Arkansas's refusal to register black pupils at its schools. In reality, this was a case of extending, through the use of force, the federal court judgment obliging the State to comply (Executive Order of 24 September 1957). It is even worth noting that, allowing for the particular features that make this case unique and incomparable to other scenarios, the United Kingdom has suspended home rule in Northern Ireland on several occasions (within the process commenced by the 1998 Good Friday Agreement). 
can be clearly deduced from Article 2 of the Constitution, which, while it 'recognizes and guarantees the right to autonomy of the nationalities and regions' that make up Spain, categorically and explicitly states that the 'Constitution is based on the indissoluble unity of the Spanish Nation, the common and indivisible country of all Spaniards' ${ }^{20}$ Article I.2 likewise clearly states that 'national sovereignty is vested in the Spanish people, from whom emanate the powers of the State'. ${ }^{21}$ What is more, as a basic teleological interpretation criterion aimed at revealing the framers' intentions, we should not lose sight of the fact that, during the preparatory talks leading up to the drafting of the Spanish Constitution, an amendment proposing the express recognition of a right to self-determination which would allow the peoples of Spain to choose between continuing to form part of the country or forming another, independent State was categorically rejected..$^{22}$

It cannot, therefore, be surprising that Spain's Constitutional Court (hereinafter 'CC'), in its (unanimous) decision on the Catalan Parliament's announcement of 23 January 2013 seeking to call a referendum in Catalonia on the grounds of a purported 'right to decide', ${ }^{23}$ declared that 'the recognition of the people of Catalonia as sovereign (...) is incompatible with Article 2 of the Spanish Constitution, as this would mean that a partial subject claiming sovereignty were granted the power to break, by its will alone, what the afore-cited Article states to be the very foundations of the Constitution: the indissoluble unity of the Spanish Nation'. ${ }^{24}$ Therefore, the CC added, 'the unconditional supremacy of the Constitution means that all decisions by public authorities must remain, without exception, subject to the Constitution, and the public authorities do not have any Constitution-free areas or windows of immunity'. ${ }^{25}$ Thus, the different appeals lodged by authorities of the Central Government over recent months against decisions by the Catalan institutions to create a number of different 'State structures' have been deemed admissible for consideration by the CC. ${ }^{26}$

${ }^{20}$ At this stage it is not necessary to remind readers that Spain's 17 Autonomous Communities have achieved a degree of self-government that is perfectly comparable to that of any Western federal State, under Title VIII of the Spanish Constitution (Articles 137 to 158 ) and its implementation through the Autonomous Communities' different Statutes of Autonomy, supported by Constitutional Court case law.

${ }_{21}$ Emphasis added.

${ }^{22}$ Amendment proposed by Mr Letamendía. It was rejected by 268 votes against, 5 votes for and in abstentions.

23 Decision $5 / \mathrm{X}$ by the Parliament of Catalonia dated 23 January 2013, declaring sovereignty and the right to decide of the people of Catalonia.

24 CC judgment 42/2014, of 25 March 2014, Legal Grounds [Fundamentos Jurídicos] section, paragraph 3. The same, CC judgment 259 /2015, loc.cit., note 5 Legal Grounds section, paragraph 4.

${ }_{25}$ Ibid, judgment 42/204, Legal Grounds section paragraph 4 (c); also judgment 429/2015, loc. cit, note 5, Legal Grounds section, paragraph 4 in fine. The judgment 259 /2015 additionally establishes that "democratic legitimacy cannot be placed at odds with constitutional lawfulness to the detriment of the later: the legitimacy of an action or policy of a public authority basically lies in whether it complies with the Constitution and the legal system. If one does not obey the Constitution, one cannot claim any legitimacy whatsoever. In a democratic conception of power, there is no other legitimacy than that established in the Constitution (...). The principle of democracy (...), being a constitutional principle, cannot be construed in isolation from the resto of the constitutional system and its processes"; Legal Grounds section, paragraph 5. Thus, "[a]n Autonomous Community's Parliament cannot set itself up as a source of legal and political legitimacy, unlawfully taking matters into its own hands in order to violate the constitutional system on which its own authority is based"; paragraph 7.

${ }_{26}$ The most important with regard to the creation of State structures abroad include, for example, an appeal lodged by Spain against the Catalan Parliamentary Act 16/2014, of 4 December, on external action and relations with the European Union (Official Spanish Gazette [BOE] number 309, 23 December 2014); appeal number 1442-2015 (challenging Articles I to 9, 26, and 29 to 38). On 14 April 2015 the CC ruled that this appeal met all the legal requisites to be admitted for consideration and several articles of the Parliamentary Act are already suspended (arts. I.I(b), 2(i)(j)(k) and (l), 4(a) and 34, 35, 36, 37 and 38) 
In line with this constitutional thinking and inspired by the German model mentioned earlier, the Spanish Constitution has its own 'federal coercion' mechanism for extreme breaches or serious attacks on Spain's general interests by an Autonomous Community. Through this mechanism, the Central Government, having first issued an injunction to the head of government of the Autonomous Community in question, and provided that the Central Government has the backing of the Senate, can force the Autonomous Community to fulfil its constitutional duties. ${ }^{27}$ Many Spanish constitutional law scholars ${ }^{28}$ have recently cited the supplementary instrument offered by the Constitution as an ultima ratio in the case, more extreme still, of the aforementioned mechanism being insufficient, and in the event of a threatened insurrection or act of force against Spain's sovereignty or independence. ${ }^{29}$ In any case, it is, perhaps, also worth reiterating that in the (German) model that inspires our federal coercion mechanism, this legal possibility operates more as a deterrent than as a mechanism of commonplace use, and, accordingly, it has never been employed in practice. That is to say, there is a wide spectrum of possible measures, including ordinary intervention by the lower courts ${ }^{30}$ and the $\mathrm{CC},{ }^{3 \mathrm{I}}$ that can be adopted before resorting to the extreme mechanisms mentioned.

A 'conflict of authority' case is also open before the CC in relation with the Generalitat's Decree creating the post of Commissioner for National Transition. This appeal was ruled to have met all legal requisites and therefore admitted for consideration by the CC on 7 July 2015 (case no. 3808-2015.

${ }^{27}$ Specifically, Article 155.I of the Spanish Constitution states that if an Autonomous Community does not fulfil the obligations imposed upon it by the Constitution or other laws, or acts in a way seriously prejudicing the general interests of Spain, the Government, after lodging a complaint with the President of the Autonomous Community and failing to receive satisfaction therefor, may, following approval granted by the overall majority of the Senate, take the measures necessary in order to compel the latter forcibly to meet said obligations, or in order to protect the above-mentioned general interests.' On the matter of how this mechanism may be implemented, Article 155.2 says no more than, 'with a view to implementing the measures provided for in the foregoing clause, the Government may issue instructions to all the authorities of the Autonomous Communities'. No implementing legislation has (yet) been put in place for the mechanism described by this constitutional rule, which has never been used in practice. Nevertheless, in 1989 the Government did go so far as to issue an injunction to the Canary Islands (at a Cabinet decision), threatening to apply Article 155 as a result of the Canaries' breach of EU law (refusal to apply a $15 \%$ tariff dismantling to products from the then EEC, as set forth in Spain's Treaty of Accession).

${ }_{28}$ See F. de Carreras, '¿Colar goles al Estado?’, El País, 20 July 2015.

29 Clearly this is the possibility of decreeing a state of siege (the most extreme form of state of emergency under Spanish law) - at the Government's proposal and provided that it is supported by an absolute majority vote from the Congress of Deputies - in the event of an actual or threatened insurrection or act of force against Spain's sovereignty, independence, territorial integrity or constitutional order that could not be resolved by any other means; Article II 6 of the Constitution and Articles 32 to 36 of Organic Law 4/198I, of I June, on States of Emergency (Official Spanish Gazette $[\mathrm{BOE}]$ number $\mathrm{134}, 5$ June $198 \mathrm{I})$.

30 In this regard it is worth noting that a number of the Generalitat's decisions to create State structures abroad have been appealed by the central government before the Administrative Division of the Superior Court of Justice of Catalonia over recent months, and that these appeals have been deemed to meet all legal requisites for consideration by said Court. This is, for example, the case of the Decree changing the title held by the Catalan Government's delegate to the EU to 'Permanent Representative of the Generalitat to the EU', using State-like terminology, Decree I/2015, of I3 January (Official Gazette of the Generalitat of Catalonia number 6789, is January 2015); or of the Decrees to open delegations of the Generalitat in Rome, Vienna, Rabat, the Holy See and Lisbon without first obtaining the (non-binding) report from the central government required under Article ir of the State Foreign Action and Service Act.

31 A non-government bill put forward by the People's Party parliamentary group on reforming Organic Law 2/1979, on the Constitutional Court, to allow, among other things, the CC to adopt measures for enforcing its judgments that guarantee such enforcement in the most effective manner possible; Organic Law 15/2015, of 16 October 2015 (BOE no. 249, of I7 October 2015). The article 92 of the Organic Law (Ley Orgánica del Tribunal Constitucional) enables the Constitutional 
III THE INTERNATIONAL LEGAL FRAMEWORK: THE INAPPLICABILITY OF THE SELF-

\section{DETERMINATION PRINCIPLE}

Having established the undisputed incompatibility of a unilateral declaration of independence with domestic law, and observed the existence of constitutional mechanisms for a legal response to a hypothetical decision made in breach of the established constitutional system, we should now delve into the international legal framework. This analysis is not going to throw up very different conclusions once we have considered I) the validity of the principle of territorial integrity, 2) the fact that the principle of self-determination does not apply to this case, 3 ) the insufficiency of a declaration of independence to reach Statehood, and 4) some reflections on the complex rules governing the succession of States.

(I) The territorial integrity principle: A key element linked to the principles of sovereignty and the domestic and international rule of law

Indeed, as we have just seen with regard to Spanish constitutional law, there are no grounds to support the existence of a right of secession under international law. To begin with, it could well be inferred from the principle of rule of law that any attempt to form a State in breach of domestic (e.g. Spanish) law is, in itself, a violation of international law. It is not for nothing that the rule-of-law principle is gaining in importance in the international community, even though its regulation is really at a very rudimentary stage of development. ${ }^{22}$

In this context -linked, above all, to the classic principle of sovereignty- the principle of territorial integrity takes on particular relevance, as it is a basic element of contemporary international law. This actually constitutes the international legal framework towards which we ought to reorient any discussion of independence aspirations based on criteria other than negotiation with the State. In this regard, Article I.3 of the Declaration of the General Assembly on the Occasion of the Fiftieth Anniversary of the United Nations expressly stipulates that any of its provisions 'shall not be construed as authorizing or encouraging any action that would dismember or impair, totally or in part, the territorial integrity or political unity of sovereign and independent States conducting themselves in compliance with the principle of equal rights and self-determination of peoples and thus possessed of a Government representing the whole people belonging to the territory without

Court to adopt new measures for like the possibility to impose a fine of 2000 to 30.000 euros on those authorities, officials or private individuals who fail to comply with decisions of the Court, with the possibility of repeating the fin until the court order is complied with fully; the possibility to suspend from their posts the authorities or officials of the Administrations responsible for such non-compliance, during the time necessary to ensure observance of the Court's decisions; the possibility to implement alternative measures in keeping with rulings delivered in constitutional procedures (with the collaboration of the Spanish Government in order to adopt the measures necessary to ensure compliance with said rulings, in the terms set forth by the court); the possibility to communicate matters having criminal relevance to the competent courts, in order to commence the criminal proceedings that may be appropriate.

32 Without going any further, this was the stand-out principle at the $67^{\text {th }}$ session of the United Nations. See, for example, the important Declaration of the High-level Meeting of the United Nations General Assembly on 24 September 2012. 
distinction of any kind'. ${ }^{33}$ Likewise the Declaration adopted by the General Assembly on 23 October 2015 on the Occasion of the Seventieth Anniversary of the United Nations reiterates the importance of the "territorial integrity" of all States (A/RES/70/3, point 5).

In this same vein, to illustrate the United Nations' position with a very recent example, we can cite the Resolution adopted by the General Assembly on 27 March 2014 entitled 'Territorial Integrity of Ukraine'. This Resolution reaffirms, on the basis of the obligations under the Charter (Article 2) and Resolution 2625 (XXV) 34 , the Assembly's 'commitment to the sovereignty, political independence, unity and territorial integrity of Ukraine within its internationally recognized borders', at the same time as it 'calls upon all States to desist and refrain from actions aimed at the partial or total disruption of the national unity and territorial integrity of Ukraine'. ${ }^{35}$ And what is of most interest here is that the Resolution from this deduces the following: 'the referendum held in the Autonomous Republic of Crimea and the city of Sevastopol on 16 March 20I4, having no validity, cannot form the basis for any alteration of the status of the Autonomous Republic of Crimea or of the city of Sevastopol'. ${ }^{36}$ In other words, if the referendum lacks legal validity at home, its result cannot have international legal validity either. Hence, if a unilateral declaration of independence made as a result of regional elections is not valid at home, legal validity cannot be sought for that same declaration abroad.

(2) The inapplicability of the self-determination principle to Catalonia: A right limited to colonized or subjected peoples

In this international legal context, it is completely impossible to eclipse the inalienable principle of territorial integrity by arguing the principle of self-determination.

With this in mind, from a purely international-law-focused perspective, the existence of a people in the strictest sense and, even more specifically, the aforesaid right to self-determination, recognized expressly in the United Nations Charter as one of its purposes (Article I.2), is only admitted under contemporary international law when very specific requirements are met.

The advocates of the right to self-determination in situations such as that of Catalonia usually base their arguments on Article I.I of both the UN Covenant on Civil and Political Rights (1966) and on Economic, Social and Cultural Rights (1966), which expressly stipulates that 'all peoples' have the right to self-determination. They also usually support their arguments with hackneyed quotes from the Declaration on Principles of International Law, which does indeed name the principle of selfdetermination and establishes that all peoples have the right 'freely to determine, without external interference, their political status and to pursue their economic, social and cultural development'. ${ }^{37}$

\footnotetext{
33 Resolution 50/6 of 9 November 1995. All of this is inseparable from the mandate of Article 2.4 of the Charter of the United Nations, which prohibits the use of any means inconsistent with the Purposes of the United Nations.

34 Resolution 2625 (XXV), of 24 October 1970, on principles of international law. See III.2 below.

35 Resolution 68/262, of 27 March 2014.

36 Ibid.

37 Resolution 2625 (XXV), of 24 October 1970.
} 
However, under current international law, there are no grounds for this affirmation being applied to a case such as that of Catalonia..$^{38}$ In the first place, a simple literal interpretation, within the context of a full reading of the two documents cited in the previous paragraph, makes it unequivocally clear that Article I.I of both Covenants refers to the populations of States and Non-Self-Governing and Trust Territories. Moreover, Resolution 2625 (XXV) dispels all doubt, clarifying that 'nothing in the foregoing paragraphs shall be construed as authorizing or encouraging any action which would dismember or impair, totally or in part, the territorial integrity or political unity of sovereign and independent States conducting themselves in compliance with [this] principle [...] and thus possessed of a government representing the whole people belonging to the territory without distinction as to race, creed or colour' ${ }^{39}$

Secondly, a teleological interpretation taking both purpose and historical context into account similarly reveals that the literal wording of the above-cited Article I.I is identical to that of Article 2 of what has become known among legal scholars as the 'Magna Carta of Decolonization', ${ }^{40}$ as the decolonizing process is the natural framework within which the right to self-determination should actually be analysed. This is not the case with Catalonia, which forms part of a democratic State which is highly decentralized and fully respects the demands derived from the rule of law and protection of human rights enshrined in the Spanish Constitution of 1978. In other words, the right of separation as a manifestation of the principle of self-determination only applies to colonial situations (the decolonization process); peoples annexed by conquest, foreign domination or occupation (the Baltic countries following the Cold War); and peoples oppressed as a result of widespread and blatant violations of their rights (South Sudan). ${ }^{4 \mathrm{I}}$

Thirdly, it is also clear that this right must be exercised in accordance with the provisions of the Charter of the United Nations and the other international law principles regulating this matter, as well as the case law of the International Court of Justice; ${ }^{42}$ a principle that shines out among these principles is the territorial integrity mentioned earlier.

Therefore, self-determination is a principle that applies in a markedly different context than that of Catalonia, and therefore its consideration as such would contravene the most basic postulations of international law on this subject.

${ }_{38}$ For just some examples, see the classical position expounded by A. Cassese, Self-Determination of Peoples: A Legal Reappraisal (Cambridge: Cambridge University Press, 1995); and many of the contributions in M. G. Kohen (ed.), Secession. International Law Perspectives (Cambridge: Cambridge University Press, 2006). See also the excellent book of X. Pons Rafols, Cataluña: Derecho a decidir y Derecho internacional (Madrid: Reus, 2015), particularly pp. I03-155.

39 According to the Resolution adopted by the UN General Assembly on the Occasion of the Fiftieth Anniversary of the United Nations, this reference to these three motives (race, creed or colour) should be interpreted in a broader sense ('without distinction of any kind').

40 Resolution I5I4 (XV), of I4 December 1960.

${ }_{41}$ See J. A. Carrillo Salcedo, 'Sobre el pretendido derecho a decidir en Derecho internacional contemporáneo', El Cronista del Estado Social y Democrático de Derecho, 33 (2012), pp. 20-22.

${ }^{42}$ For example, the ICJ's advisory opinion on Legal Consequences of the Construction of a Wall in the Occupied Palestinian Territory (2004); advisory opinion on Western Sabara (1975); judgment on East Timor, (1995), etc. 
(3) The practical importance of recognition: Impossible when a State is formed in violation of the law In any case, if, despite its illegality, a de facto unilateral declaration of independence were to take place, it is worth bearing in mind that, under international law, such a declaration is not in any way sufficient for a new State to be considered to exist. Of course, from the very beginning, all the usual requirements - territory, population, government (understood as the capacity for self-organization, in turn conceived as the capacity to maintain international relations independently and not as a dependent of a third party) - should exist. But beyond this, the international legal system does not establish the precise criteria needed to consider when a new State has come into existence. Therefore, in practice, to confirm its actual existence, as well as meeting the above conditions, the new State must also be recognized as such by the international community. ${ }^{43}$

Nevertheless, although when all is said and done, the recognition of a State obviously has a major legal impact on relations between States and/or international organizations, recognition does not in itself constitute grounds for arguing the State's existence. ${ }^{44}$ Although freedom of (express or implicit) recognition exists as a rule, this freedom has some limits. Firstly, premature recognition -i.e. when, as is the case here, the conditions required for the new State to exist have not yet arisen, seeing that this State is, at best, a 'work in progress' - is not valid, and doing so could even be considered as meddling in the domestic affairs of the State of which the territory with aspirations of independence continues to form part. Secondly, according to the prevailing opinion at the United Nations, if a new State has been formed illegally - for example, by way of an invalid referendum - the States of the international community are required to abstain from recognizing the new State. Specifically, the above-cited Resolution on the territorial integrity of Ukraine adopted by the General Assembly on 27 March 20I4, 'calls upon all States, international organizations and specialized agencies not to recognize any alteration of the status of the Autonomous Republic of Crimea and the city of Sevastopol on the basis of the above-mentioned referendum and to refrain from any action or dealing that might be interpreted as recognizing any such altered status' ${ }^{45}$ And this is not in any way an isolated case. Remember that, in practice, prior to the specific case of Ukraine, the Security Council took an almost identical position with regard to the unilateral declarations of independence of South Ossetia and Abkhazia, reaffirming 'the commitment of all Member States to the sovereignty, independence and territorial integrity of Georgia within its internationally recognized borders' ${ }^{46}$ This is not just empty rhetoric. ${ }^{47}$ Similar examples of calls by the Security Council to refrain from

43 A work that continues to provide great assistance in studying this issue is J. Quel López, 'La práctica reciente en materia de reconocimiento de Estados: problemas en presencia', in Cursos de Derecho Internacional de Vitoria-Gasteiz de 1992 (Vitoria, 1993), pp. 39-82.

44 This does not appear to be the right time to reopen the old debate of declarative versus constitutive theories regarding the effects of recognition of States. In the present status of development of international law, this author believes there are no longer any legal arguments sustaining the validity of the second of these theories.

45 Resolution 68/262.

46 Resolution I808 (2008), of 15 April.

47 Consider that the international community has not acknowledged the statehood of South Ossetia and Abkhazia. Only Russia and four more States (Venezuela, Nicaragua, Nauru and Tuvalu) have done so, aside from mutual recognitions by other similar territories such as Transnistria and Nagorno-Karabakh, placing them in a kind of legal limbo as de facto political entities. 
recognizing territories can also be found in well-known cases such as that of the Turkish Republic of Northern Cyprus.

The author's understanding is that this is unchanged by the International Court of Justice (ICJ)'s oft-quoted advisory opinion on Kosovo of 22 July 2010 - firstly, because the ICJ stipulated that Kosovo's declaration of independence of 17 February 2008 'did not violate general international law';48 secondly, because the ICJ was not even asked whether international law gave Kosovo 'positive entitlement' to declare its independence and did not take any stance on this issue;49 and, thirdly, because the sui generis nature of the case of Kosovo was made perfectly clear, given, for instance, the prior intervention by the United Nations and human rights violations on a massive scale. ${ }^{5 \circ}$ In the case under discussion here, a unilateral declaration of independence would be illegal (from a domestic legal perspective and therefore also from an international one) and there are none of the circumstances that could, legally speaking, render our case comparable to the case law produced by the ICJ on a sui generis basis in its advisory opinion on Kosovo. The advisory opinion issued by the ICJ on Kosovo cannot be transferred to the case of Catalonia. To begin with, we should not lose sight of the fact that the Court was not asked-and consequently, took no position regarding-whether international law conferred 'positive entitlement' on Kosovo to declare its independence. ${ }^{5 \mathrm{I}}$ Moreover, the obvious difference between a territory that has been subject to atrocities that violate the most basic principles of international law, on the one hand, and a territory with a democratic constitution based on the rule of law and which recognizes a very high degree of political decentralization and devolution of powers, on the other, is clearly no trivial matter..

(4) Succession of States: Various problems and the impossibility of belonging to international organizations

At this point it is no longer necessary to present any more international-law-based theories countering a unilateral declaration of independence made in contravention of both domestic and international legislation and which should not result in recognition (whether express nor implicit) of Statehood by the rest of the international community (States and international organizations including, of course, the European Union). Be that as it may, for illustrative purposes, it is also worth considering the matter of the succession of States; in other words, what would happen from a legal perspective if, despite all that has been said above, part of a national territory were successful in its aspiration to form a new State.

In the case of the separation of part of the territory of a State aiming to become a new State, the legal consequences are regulated in international law under the institution known as the 'succession of States'. There are two international Conventions that regulate these issues, although they have (so far)

${ }_{48}$ Advisory opinion on Kosovo, ICJ Rep 20Io, para. 84.

49 Ibid, para. 56.

so For a critical approach to this controversial ICJ advisory opinion, see Alegría Borrás (ed.), La independencia de Kosovo ante la Corte Internacional de Justicia: la opinión consultiva de la Corte Internacional de Justicia de 22 de julio de 2010 sobre la conformidad con el derecho internacional de la declaración unilateral de independencia de Kosovo (Madrid: Marcial Pons, 20II); also published in Revista Española de Derecho Internacional, (63:I) $201 \mathrm{I}$.

${ }^{51}$ Para. 56. 
failed to achieve the universality they seek, due to either not yet having entered into force ${ }^{52}$ or having a limited number of ratifications to date..$^{53}$ In any case, all existing provisions regarding the succession of States assume, once again, that the separation has taken place in accordance with general international law. Thus, the two Conventions at hand expressly state that they apply 'only to the effects of a succession of States occurring in conformity with international law and, in particular, with the principles of international law embodied in the Charter of the United Nations', ${ }^{54}$ which, to begin with, is not the case here - and this is no trifling matter.

A closer look at the solutions proffered reveals a certain amount of ambiguity. Regarding succession of states in respect of treaties, the Vienna Convention on this subject ${ }^{55}$ aims to systematize the rule that treaties will continue to apply to the territory of the new State. ${ }^{56} \mathrm{It}$ is, however, worth bearing in mind that this particular Convention has been ratified by only 22 States, ${ }^{57}$ that Spain is not among them, that only some of its provisions can be considered customary law, ${ }^{58}$ that the Convention par excellence on the subject of treaties keeps silent on such issues, 59 that a great deal of vagueness (not to mention contradictory practices ${ }^{60}$ ) can be observed in international practice, ${ }^{61}$ and that legal scholarship has been particularly critical, from day one, with the regulation set forth in the Convention on Succession of States in Respect of Treaties. ${ }^{62}$ The solution will actually vary considerably depending on the nature and content of the treaty in question. Firstly, as regards territorial treaties relating to borders, the utilization of international rivers or other territorial uses, both international practice and ICJ case law make it very clear that the principle of continuity is fully

52 Vienna Convention on Succession of States in respect of State Property, Archives and Debts, of 8 April 1983. This Convention has received only seven of the 15 ratifications necessary for it to enter into force. Spain is not among the ratifying countries.

53 Vienna Convention on Succession of States in respect of Treaties, of 23 August 1978. This Convention entered into force on 6 November 1996, although it has been ratified by only 22 States.

54 Article 6 of the 1978 Convention and Article 3 of the 1983 Convention.

55 See C. Gutíerrez Espada, 'Sobre la sucesión de Estados en materia de tratados', in AA.VV., Hacia un nuevo orden internacional y europeo - Libro bomenaje al profesor Diez de Velasco, (Madrid: Tecnos, 1993), pp. 36I-375, particularly pp. 370375 ( 'potential current applicability of the subject').

${ }_{56}$ Article 34.I of the Vienna Convention on Succession of States in respect of Treaties stipulates that 'when a part or parts of the territory of a State separate to form one or more States, whether or not the predecessor State continues to exist: (a) any treaty in force at the date of the succession of States in respect of the entire territory of the predecessor State continues in force in respect of each successor State so formed (...)'.

57 These include only three European Union Member States, and they not exactly the most significant for this purpose (the Czech Republic, Slovakia and Slovenia).

58 Gabcikovo-Nagymaros Project (Hungary/Slovakia), ICJ judgment of 25 September 1997, Rep. 1997.

59 Article 73 of the Vienna Convention on the Law of Treaties, of 23 March 1969, expressly excludes the succession of States as regards treaties from the scope of said Convention.

60 See P. Eiseman and M. Koskenniemi (eds.), State Succession: Codification tested against the facts-La succession d'États: La codification à l'épreuve des faits (Leiden-The Hague-Boston: Martinus Nijhoff/Brill, 2000).

${ }_{61}$ In practice, something of a trend away from the 'blank slate' principle and towards a certain degree of continuity does exist, but this is still at a very early stage; P. Dumberry, and D. Turp, 'La succession d'États en matière de traités et le cas de la sécession: du principe de la table rase à l'émergence d'une présomption de continuité des traités', Revue Belge de Droit International, 36(2003), pp. 377-412.

${ }_{62}$ For example, see Annie Gruber's doctoral thesis, in which she asserts that 'les thèses défendues par la doctrine des nouveaux États en matière successorale obéissent... au schéma d'une logique passionnelle parfaitement indifférente aux exigénces de la logique juridique classique, rationnelle et cartésienne', Le droit international de la succession d'États (Brussels: Bruylant, 1986), p. 280. 
valid with a view to safeguarding the principle of stability. Secondly, for multilateral treaties on human rights and humanitarian law, although there is no sufficiently clear legal backing, arguments of weight could also be found to support the idea of continuity. But for other treaties, it is perfectly feasible to maintain that the predecessor State's treaties would cease to be in force and would have to be negotiated anew by the new State. ${ }^{63}$ It should, moreover, be acknowledged that there is a great deal of uncertainty and casuistry depending the content or nature (bilateral or multilateral) of a given treaty, ${ }^{64}$ meaning that, in practice, the will of the third State involved can also turn out to be crucial. ${ }^{65}$ It is not without good reason that reputable legal scholars have argued that the Convention 'gives no warning of the importance of the disposition of the other parties in bilateral and multilateral treaties, because without their willingness it is impossible for the rights and obligations to pass to the successor-in-interest, as the question of who is bound by the treaty is no irrelevant matter to the other parties'. ${ }^{66}$

As for succession in the field of debt, understood as 'any financial obligation of a predecessor State arising in conformity with international law towards another State, an international organization or any other subject of international law, ${ }^{67}$ in principle, what matters is an agreement among the parties concerned. Where no such agreement is reached, the criterion followed in international law is that of a fair and proportional transferral of debt. In other words, there is no blank slate' principle, so the new State must contribute (fairly) to the payment of existing debts. ${ }^{68}$

An identical criterion of fair distribution also applies to the distribution of property, understood to be the 'property, rights and interests which, at the date of the succession of States, were, according to the internal law of the predecessor State, owned by that State'. ${ }^{69}$ In other words, the two States would have to reach an agreement..$^{70}$ Broadly speaking, it could be assumed that Spain would continue to own all of its existing property, although any real or personal property of the predecessor State

${ }_{63}$ In the Spanish international law community, Antonio Remiro Brotons very rightly judges that whenever 'a traumatic separation takes place, continuity is debatable to say the least, as practice implies that the normal thing would be for the new State to try to assert and consolidate its international personality by getting its own way in the question of succession' in ibid. et al., Derecho Internacional (Valencia: Tirant lo Blanch, 2007), p. 492.

${ }_{64}$ P. Pazartzis, La succession d'États aux traités multilatéraux: à la lumière des mutations territoriales récentes (Paris: Pedone, 2002).

${ }_{65}$ There is past precedent of treaties that, with a view to ensuring legal certainty, have also continued to apply to the successor State. This was, for example, the case of the USSR's double taxation treaties. In the specific case of Spain, double taxation treaties have remained in force for the States of the former USSR, with the exception of countries with which new conventions have since been signed, such as Armenia (since 2007), Azerbaijan (since 2008), Georgia (since 2007), Kazakhstan (since 2008), Uzbekistan (since 2010) and Moldova (since 2007).

66 Remiro Brotons et al, op. cit. (Derecho Internacional), note 63, p. 491.

67 Article 33 of the 1983 Vienna Convention.

68 Article 40 of the 1983 Vienna Convention therefore stipulates that 'when part or parts of the territory of a State separate from that State and form a State, and unless the predecessor State and the successor State otherwise agree, the State debt of the predecessor State shall pass to the successor State in an equitable proportion, taking into account, in particular, the property, rights and interests which pass to the successor State in relation to that State debt'.

69 Article 8 of the 1983 Vienna Convention.

7o For more information see G. Ress, 'La succession d'États en matière de biens et d'obligations', Annuaire de l'Institut de Droit International 2000-200I (session de Vancouver), 69:2003 (París: Pedone), pp. II9-440. 
(Spain) located in (or linked to) the purported new State (Catalonia) could perhaps become the latter's property. ${ }^{71}$

Meanwhile, international law sheds no much light on the issue of citizenship in the succession of States. The matter is not subject to any treaty, there is no settled customary law, and international practice is inconsistent..$^{72}$ However, in general terms, it can be assumed - with all the necessary caveats - that the governing principle would be an automatic change of citizenship, although this would have to be tempered with other elements, derived, to a large extent, from the principle of selfdetermination, but also - and above all- driven by the need to safeguard individuals' fundamental rights. ${ }^{73}$ Therefore, should Catalonia become an independent State, its citizens would hold Catalan citizenship, as citizenship is the legal link binding the new State to its citizens. However, as international law remits to domestic law, in this case we would also have to consider the provisions set down in Spanish law, basically the Constitution (Article Ir.2) and the Civil Code (Articles 24 and 25); ${ }^{74}$ in any case, the transition from Spanish to Catalan citizenship would have to take place gradually and with sufficient safeguards to ensure the preservation of the rights of those Spanish nationals resident in the new State wishing to keep their Spanish citizenship. Similarly, in the (unlikely) event that independence were to materialize, it is plausible to assume that the predecessor State would have to seek suitable mechanisms to prevent an evasion of the law ${ }^{75}$ in the form of an attempt to hold onto European citizenship through dual (Spanish and Catalan) citizenship. ${ }^{76}$ In fact,

7 Article 17 of the 1983 Vienna Convention.

72 The classic debate as to whether citizenship is a matter of domestic or international law is very familiar to international law scholars. Nowadays nobody questions whether authority to grant or deny citizenship lies with each individual State, albeit with certain limits derived from international law. The root of the problem lies in the fact that, as international law currently stands, there are no clear, commonly accepted rules. The most that has been achieved is the preparation of draft articles by the International Law Commission, Resolution 55/153 Nationality of Natural Persons in Relation to the Succession of States, A/RES/55/153 of 30 January 2001 .

73 For examples from Spanish scholars, see the doctoral thesis of M.I. Torres Cazorla, La sucesión de Estados y sus efectos sobre la nacionalidad de las personas, (Malaga: Universidad de Málaga, 200I), particularly pp. 397-398.

74 The Spanish Constitution guarantees that 'no person of Spanish origin may be deprived of his nationality' (Article II.2). The Civil Code upholds the safeguarding of rights, although it does set forth circumstances in which citizenship can be lost in the case of emancipated individuals whose main residence is abroad and who voluntarily acquire another nationality (with the requirement that three years pass) or individuals who expressly relinquish their citizenship (Articles 24.I and 24.2). It is, therefore, possible to lose one's citizenship through voluntary, express relinquishment and also through possession of another country's citizenship, which, in the hypothetical scenario of an independent Catalonia, it is assumed would be the case of those who opted for the new State's citizenship.

75 Defenders of the separatist process have continued to argue the possibility of keeping hold of Spanish citizenship and adding it to the new Catalan citizenship, and, therefore-and despite living in a non-EU State-keeping hold of the citizenship entitlements linked to the nationality of the State from which Catalonia would hypothetically have seceded. See, for example, E. Sagarra i Trias, 'Nacionalidad catalana, nacionalidad española y ciudanía de la Unión: ¿serían compatibles?', Revista de Derecho Migratorio y Extranjería (36:2014); ibid, Ciudadanía y nacionalidad futura en una Catalunya independiente, report by the Miquel Roca law firm (Barcelona, 2014); available at http://nabarralde.com. In the opinion of this paper's author, this interpretation leads to the absurdity of defending Catalonia being a separate State whose citizens would hold its (new) citizenship while also retaining the nationality of the State from which Catalonia had unilaterally seceded in a flagrant breach of the Spanish legal system, while, moreover, hoping that this would be accepted without any reaction from Spain. What this aspiration comes down to is something equivalent to the new State being allowed to pick and choose from the predecessor State's Constitution 'à la carte' ('yes to Article II; no to Article 2; an independent state with its own citizenship, but also that of the predecessor State...').

${ }^{6}$ See IV.3 and IV.4 below. 
nothing in international law prevents a predecessor State from withdrawing citizenship from those who acquire the successor State's nationality. ${ }^{77}$

Finally, turning to the matter of membership of international organizations, international law does not accept succession in relation to the multilateral founding treaties of such organizations. Therefore, Spain would remain a member of all the international organizations to which it currently belongs (in some cases certain internal adjustments to conditions could be required as a result of the reductions of its territory and population), whereas the new State would be left out. ${ }^{7}$ If the new State then wished to join any of these international organizations, starting with the UN, it would have to meet the admission requirements set forth in their respective founding treaties, and, therefore, negotiate the terms of accession just like any other candidate State; in fact, it would not even be able to gain observer status ${ }^{79}$ at many of the leading international organizations -again, starting with the $\mathrm{UN}^{8},^{80}$

77 The first section of the International Law Commission's draft Article io on the nationality of natural persons in relation to the succession of States stipulates that 'a predecessor State may provide that persons concerned who, in relation to the succession of States, voluntarily acquire the nationality of a successor State shall lose its nationality'; Resolution $55 / 153$.

$7^{8}$ For a more nuanced discussion introducing non-legal elements from international politics, see K.G. Bühler, State succession and membership in international organizations: Legal theories versus political pragmatism (The Hague: Kluwer Law International-Martinus Nijhoff, 200I).

79 This status is not legally regulated in the legislation of the United Nations and its legal value is relative. Nonetheless, there is a recent precedent in the General Assembly's practice in this respect. This is, basically, the case of Resolution 67/19 of 29 November 2012, according Palestine 'non-member observer State status in the United Nations'. There is not, therefore, much legal difficulty involved in observer status. In fact, there is accepted past practice on the matter of gaining this status, and in the case in question it had already been recognized (Resolution 3237 (XXIX) of 22 November 1974) and the General Assembly had issued a formal invitation to the Palestine Liberation Organization to participate in its deliberations as the representative of the Palestinian people (Resolution 3210 (XXIX), of I4 October 1974); a number of additional rights and privileges attached to this observer status had even been recognized (Resolution 52/250 of 7 July 1988). However, there is more difficulty involved in classification as a State. It appears clear that this is a necessary pre-condition. In the case of Palestine, until that moment the General Assembly had previously 'acknowledged' the proclamation of the State of Palestine by the Palestine National Council (Resolution 43/177, of 15 December 1988), and decided that the designation 'Palestine' would be used in place of the designation 'Palestine Liberation Organization' within the United Nations system (Resolution 43/177). But Resolution 67/19 adds the consideration as a State, albeit with certain caveats added into the wording of the Resolution (see, for example, paragraphs I, 3, 4, 5 and 6), but a State in any case.

And that is, once again, the essential factor: the existence of a State in the eyes of the United Nations. One cannot overlook the fact that, prior to this United Nations General Assembly Resolution, the Palestinian National Authority had already been accepted as a full member of many organizations and bodies (such as UNESCO, the Economic and Social Commission for Western Asia, the League of Arab States, the Non-Aligned Movement, the Organisation of Islamic Cooperation, the Group of 77 and China). Moreover, unlike the case of Catalonia, the General Assembly has clearly reiterated 'the right of the Palestinian people to self-determination and to independence in their State of Palestine on the Palestinian territory occupied since 1967'. Moreover, this is 'without prejudice to the acquired rights, privileges and role of the Palestine Liberation Organization in the United Nations as the representative of the Palestinian people, in accordance with the relevant resolutions and practice' (paragraph I). Similarly, after expressing the hope that the Security Council will approve Palestine's application for admission to full membership of the United Nations (paragraph 3), the Resolution urges 'all States and the specialized agencies and organizations of the United Nations system to continue to support and assist the Palestinian people in the early realization of their right to self-determination, independence and freedom' (paragraph 6).

It does not appear necessary to go into detail as to why Catalonia can in no way be considered an occupied territory. As has already been shown, the United Nations has not recognized (and cannot recognize) a right to self-determination for Catalonia. A hypothetical aspiration by Catalonia to obtain observer status at the United Nations General Assembly would, therefore, not be legally feasible.

so To be a member of the United Nations, a number of formal and substantive requirements must be met. Formally speaking, the admission of a new Member State requires a two-thirds majority vote in favour from the General Assembly, and a nine-vote recommendation from the Security Council, including votes in favour from all five permanent members 
and also NATO ${ }^{8 \mathrm{r}}$ This situation is particularly significant in the case of the European Union, so this organization deserves a closer look in the next section.

\section{THE EU LEGAL FRAMEWORK: THE IMPOSSIBILITY OF REMAINING AUTOMATICALLY IN}

\section{THE EU IN THE EVENT OF INDEPENDENCE}

Now that we have analysed the domestic and international law sides of this issue in the two preceding sections and established, for analytical purposes, a hypothetical scenario in which Catalonia gains independence from Spain (in breach of the legislation currently in force), we should now consider the impact of this hypothetical scenario from a European Union law perspective. And, in this regard, the author feels he is not going too far in revealing, right here in the introduction, that the Union's legal system is considerably more explicit, clear and categorical than we have just observed international law to be. Thus, I) although in practice there is no comparable precedent, 2) there are sufficient legal arguments to sustain that, within the framework of the consideration of the Union as a 'Union of States', 3) the proposed internal enlargement theory is, quite simply, unsustainable, as 4) citizenship of the European Union is inextricably linked to the citizenship of an EU Member State.

\section{(I) Lack of precedent in EU practice:}

\section{Greenland, Algeria and the reunification of Germany}

We should begin by acknowledging that previous EU practice is void of any precedent that could be comparable to the issue discussed here. Certainly, the matter has been discussed on a theoretical level with regard to other territories, such as Scotland or Belgium, but these discussions have never made it beyond theory and into reality. There have, however, been a number of cases of modifications to a State's territory in relation to the application of EU law from which some lessons could be drawn. Although the following cases have absolutely nothing in common with the matter discussed here, we

(Articles 4.2, 18.2 and 27.3 of the Charter of the United Nations; Articles 58, 59 and 60 of the Provisional Rules of Procedure of the Security Council; Articles 134 to 138 of the Rules of Procedure of the General Assembly).

The substantive requirements are of particular interest, since if they are not met, going on to examine the aforementioned decisions by the General Assembly and Security Council is unthinkable. The Charter requires UN members to be 'peace-loving states which accept the obligations contained in the present Charter and, in the judgment of the Organization, are able and willing to carry out these obligations' (Article 4.I). In other words, under the UN Charter, being a State is an essential precondition for admission as a member of the United Nations. Therefore, if, as has been argued in the preceding sections, statehood is not held, membership of the United Nations is not in any way possible. As has also been explained already, the bodies of the United Nations (the General Assembly and Security Council) that are responsible for deciding on membership applications have demanded that all States and international organizations respect the 'commitment to the sovereignty, political independence, unity and territorial integrity' when a unilateral declaration of independence is made illegally, in addition to calling 'upon all States to desist and refrain from actions aimed at the partial or total disruption of the national unity and territorial integrity' of such territories, including-of course-the requirement to refrain from recognizing them (whether expressly or implicitly) as States.

As the first of the requirements set forth in the Charter for membership of the United Nations is not met, it is unnecessary to now analyse the other four requirements, although it appears clear that some of them (respecting the principles of the Charter or being able to carry out the obligations derived from membership) would also not be met.

${ }^{8 \mathrm{r}}$ Article Io of the Washington Treaty of 1949 makes being a State a requirement for joining NATO and requires the unanimous agreement of all States Parties. 
could examine Algeria's independence from France (1962); the ceasing of application of Community law in Greenland, despite its continuing as part of Denmark (1985); and the reunification of Germany (1990).

Algeria is a clear case of decolonization resulting in its secession and exit from the Community. Algeria had previously been given the same consideration as the French overseas departments of Martinique, Guadeloupe, French Guiana and Réunion (Article 227.2 of what was then the Treaty establishing the European Economic Community) and its secession was never set down in a legal document, so the founding treaties continued to contain formal references to Algeria until Maastricht. $^{82}$

In the case of Greenland, there was no change to the territory of the Member State in question (Denmark), but rather, at the will of that State itself and as a result of a greater degree of selfgovernment conferred upon the territory (1979), Community law ceased to be applied in Greenland at the decision of its own citizens in a referendum (1982). ${ }^{83}$ Nonetheless, Greenland continued-and continues-to form part of Denmark. Understandably, this required the founding treaties to be amended accordingly, ${ }^{84}$ followed by ratification by all Member States. ${ }^{85}$

In the unique case of the German reunification, one Member State (the Federal Republic of Germany) absorbed a third State (the German Democratic Republic) as expressly set forth in what was then Article 23 of the Bonn Basic Law. ${ }^{86}$ As a result, negotiations had to take place between the State in question and the Community institutions in order to adapt the application of Community law (institutional and substantive) to the circumstances of a State whose territory had been enlarged to include five new Länder. ${ }^{87}$ But all of this was, logically, based on the pre-existing full support of all

82 The founding treaties of what were then the European Communities originally considered Algeria as a French overseas territory. When it became independent (1962), the application of the treaties logically ceased de facto, but it is worth remembering that the wording of what was then Article 227.2 of the Treaty establishing the European Economic Community was not modified de jure until the Treaty of Maastricht (1992). And in fact, from 1962 to 1992 the issue was not subject to any ad hoc regulation in secondary law. Community law simply ceased to apply, and, de facto, the European institutions adopted the measures necessary to accept the independence process, in which they had not intervened before or after independence.

83 F. Harhoff, 'Greenland's withdrawal from the European Communities', Common Market Law Review (1983), pp. I3-33.

${ }^{84}$ Official Journal L 29 of I February 1985. From that moment onwards, Greenland become one of the territories listed in Annex IV of what was then the Treaty Establishing the European Community, and is now Annex II, Overseas countries and territories to which the provisions of part four [i.e. Articles 198 to 204 TFEU] of the Treaty on the Functioning of the European Union apply.

${ }_{85}$ The process of negotiating the reform of these treaties was based on a memorandum submitted by Danish government and accepted by the rest of the Member States; Official Journal C I84 of II July I983.

86 This provision, according to the wording adopted in 1949 which remained in place until the German reunification, stipulated that the Basic Law of Bonn was to apply initially to the Länder of the Federal Republic of Germany ('Dieses Grundgesetz gilt zunächst im Gebiet der Länder Baden, Bayern, Bremen, Gross-Berlin, Hamburg, Hessen, Niedersachsen, Nordrbein-Westfalen, Rbeinland Pfalz, Scbleswig-Holstein, Wüttemberg-Baden und Wüttemberg-Hozenbozöllern'). But it immediately followed this statement with the provision that it would also apply to other parts of Germany once they had joined the Federal Republic ('In anderen Teilen Deutscbland ist es nach deren Beitritt in Kraft getretten').

${ }_{87}$ Stand-out works among the vast amount of literature on the German reunification are C.W.A. Timmermans, 'German Unification and Community Law', Common Market Law Review (27:1990), pp. 415-436; H. Glaesner, 'Les problèmes de droit communautaire soulevés par l'unification allemande', Revue du Marché Commun (341:1990), pp. 647-654; K. Hailbronner, 'Völker- und europarechtliche Fragen der deutschen Wiedervereinigung', Juristenzeitung (1990), p. 449; T. 
Member States for the proposed reunification (by absorption) of one of the States ${ }^{88}$ not the separation of part of a State. ${ }^{89}$

It would therefore seem apparent that none of these precedents have any relation whatsoever with the case at hand here. We can, nonetheless, extract two clear conclusions from these experiences: firstly, that it is not up to the Union to decide on possible mutations of the territory of its Member States - this falls within the jurisdiction of the States themselves, and the Union only intervenes to regulate the resulting impact on the European legal framework - and, secondly, that we cannot speak of European Union member territories, but rather of Member States with regard to whose territory the founding treaties can establish possible modulations where applicable.

However, the fact that in practice there is no precedent of similar cases to the one being analysed here does not mean that EU law does not offer more than sufficient substance for legally resolving an issue of the kind that could arise in Catalonia if a unilateral declaration of independence were eventually made. Quite the opposite in fact: the legal scenario is, in this author's understanding, crystal clear.

(2) The European Union as a Union of States: A requirement to guarantee Member States' territorial integrity

It is worth remembering here that the European Union is a 'Union of States'. Undoubtedly, the position occupied by the EU citizen is unparalleled in the rest of the world's international organizations; ${ }^{\circ}$ moreover, the EU is endowed with powers of a quantity and intensity that, coupled with unique characteristics of a supranational (or even federal) nature, distance it from any other international organization..$^{91}$ Nevertheless, these unique features do not, in any way, change the clear premise that the High Contracting Parties of the EU's founding treaties are the States (Article I of the Treaty on European Union, or TEU) and that these treaties are applied to the States (Article 52.I TEU) with the specific territorial idiosyncrasies that the treaties themselves establish, at the request of the individual States (Article 52.2 TEU and 355 of the Treaty on the Functioning of the European

Giegerich, 'Die Europäische Dimension der deutschen Wiedervereinigung', Juristische Schulung (1991), p. 996-1002 (also available in English in Zeitschrift für ausländisches öffentliches Recht und Völkerrecht (51:199I), pp. 384-450).

88 In actual fact, its unusual status following the Second World War meant it was necessary to sign the Treaty on the Final Settlement with Respect to Germany between the Republics (FRG and GDR) and the four occupying powers (the '2+4 Treaty'), of I2 September 1990 (in force as of I5 March 1991).

89 On 28 April 1990 the European Council declared its support for the process commenced by the Federal Republic of Germany to incorporate the former German Democratic Republic into its territory; see Revista de Instituciones Europeas (1990), pp. 295-304, particularly pp. 296-297. The Council stipulated that 'the Community will ensure that the integration of the territory of the German Democratic Republic into the Community is accomplished in a smooth and harmonious way', at the same time as inviting the Commission to 'submit [...] proposals for such [transitional] measures as are deemed necessary'. It considered that 'it will be carried out without revision of the Treaties'. From then on, the Commission was responsible for the gradual adoption of these transitional measures, not without causing certain friction with the European Parliament.

90 The citizen does, indeed, hold rights of citizenship per se (Article 20 to 25 TFEU and Articles 39 to 46 of the EU Charter of Fundamental Rights) and is also granted a legal status for certain cases in which citizens are able to take direct action with the institutions of the Union (lodging of actions of annulment and actions for failure to act before the Court of Justice). The European citizen is also entitled to human rights (for instance, Articles I to 5 of the EU Charter of Fundamental Rights).

${ }_{91}$ On this issue, please see the author's paper, 'The Federal Elements of the European Union', Zeitschrift für Europarechtliche Studien (200I), pp. 595-625. 
Union, or TFEU). In short, to use the now-classic words of the German Constitutional Court, the States are 'die Herren der Verträge' - in other words, the lords and masters of the treaties'.

Moreover, primary EU law expressly recognizes the European Union's duty to respect 'the national identities' of its Member States, 'inherent in their fundamental structures, political and constitutional, inclusive of regional and local self-government' (Article 4.2 TEU)..$^{2}$ Article 4.2 even adds with full clarity that the Union 'shall respect their essential State functions, including ensuring the territorial integrity of the State, maintaining law and order and safeguarding national security'. In other words - and it could not be any other way- the Union has to ensure respect for the authority of the Member States to guarantee their own 'territorial integrity'. ${ }^{93}$ And, logically, it also has to respect (and endorse) the legality of any decisions that the courts of the State concerned, such as the Spanish Constitutional Court, may adopt in accordance with the requirements of the rule of law derived from the legal and constitutional system in question. ${ }^{94}$ We should not lose sight of the fact that, even in the case of non-EU territories, the European institutions have, in practice, a tendency to be highly reluctant to recognize new States resulting from the breakup of a previous State until they are provided with cold, hard evidence of the fact that the new State has become irreversibly consolidated. The precedent provided by the breakups of Yugoslavia and the USSR is a good example of the Union's cautious approach to these situations. ${ }^{95}$

In this same vein, it is the author's understanding that is it entirely delusional, unfounded and mistaken to believe that an EU Member State's refusal to recognize that part of its territory were entitled to a purported 'right to decide' would drive the European Union's institutions to employ the mechanism provided for in Article 7 of the TEU, ${ }^{96}$ which is intended solely and exclusively for a 'serious and persistent breach' of fundamental rights. ${ }^{97}$

${ }_{92}$ For more details see C. Callies, 'Art. 4', in EUV/AEUV - Das Verfassungsrecht der Europäischen Union mit Europäischer Grundrechtecharta, ed. by C. Callies and M. Ruffert (Munich: C.H. Beck, 20II), pp. 54-II2, particularly pp. 6064, sections 13 to $2 \mathrm{I}$; with additional theoretical references on pp. 54-55.

93 Obviously, the Union does not have any power to oppose modifications by Member States to the borders that make up their territory. This is the exclusive jurisdiction of each State, to be exercised in accordance with its domestic legal system, and, where applicable, of any third States that could also be affected.

94 See section II above.

95 In this same vein, see M. Campins Eritja, 'The European Union and the Secession of a Territory from a EU Member State' Diritto Publico Comparato ed Europeo (2:2015), pp. 479-502, particularly p. 464. Even more categorical is V. Constantinesco, 'La politique de l'Union européenne fâce au phénomenon de la fragmentation des États: de l'ex Yougoslavie aux Balkans occidentaux', in États fragmentés ed. by S. Pierré-Caps and J.D. Mouton (Nancy: Presses Universitaries de Nancy, Collection Cap Europe, 2012), pp. 143-164.

${ }_{96}$ For more on this issue see A. González Bondía, 'La Unión Europea ante el reto del derecho a decidir', in ¿Existe el derecho a decidir? Preguntas y respuestas sobre el proceso abierto en Cataluña, ed. by E. Segarra (Barcelona: Tibidabo 20I4), pp. I23-I46; J. Ridao Martín, 'La Unió Europea i els nous Estats sorgits per secessió dels seus membres. Una hipòtesi per Catalunya', Revista Jurídica de Catalunya, II3 (2014), pp. 33I-353; J. Ridao Martín and A. González Bondía, 'La Unión Europea ante la eventual creación de nuevos Estados surgidos de la secesión de Estados miembros', Revista de Derecho de la Unión Europea, 27-28 (2014), pp. 363-390. A direct reply to this last work can be found in E. Linde Paniagua, 'Contestación al trabajo de Ridao-González: la secesión de territorios de Estados miembros de la Unión Europea, que se fundan en ideologías nacionalistas, son contrarias a los principios democráticos que rigen en los Estados occidentales y en la Unión Europea', Revista de Derecho de la Unión Europea, 27-28 (2014), pp. 39I-4I2.

97 Indeed, this important rule gives the European Council the possibility-at the proposal of one third of member States or the Commission, and once the motion has been passed by the European Parliament-of unanimously declaring 
Finally, it is also worth clarifying that the unilateral secession of part of a State and the possibility of withdrawal of a Member State - provided for by the founding treaties since the entry into force of the Lisbon Treaty - are two entirely different things. The case of withdrawal is provided for expressis verbis in the founding treaties; the procedure is regulated in detail; it affects the entire Member State in question; and it is based on an agreement negotiated with the European Union..$^{98}$

In view of this, an independent Catalonia seeking admission into the international community as a new State ${ }^{99}$ would ipso facto be left out of the European Union. It would, to all intents and purposes, be a new State and, if it wished to join the Union, it would have to undergo the accession procedure expressly provided for in the founding treaties (Article 49 TEU). Assuming, of course, that this new (aspiring) State could be considered a State in the sense required under EU law, and that it met the objectives and values demanded by the Union (Article 2 TEU) and were committed to promoting them, it could then apply to join the Union (Article $49 \mathrm{TEU}$ ). In any case, it would have to submit its application to the Council, which would have to reach a unanimous decision - in other words, any one of the current 28 member States, including Spain of course, would have a veto- once the Commission had been consulted and the motion had been approved by a majority vote at the European Parliament. Moreover, Catalonia would, at the same time, have to negotiate an accession agreement establishing the conditions for its accession, and this would also require ratification by all Member States in accordance with their domestic constitutional arrangements. This, of course, would also include Spain, so there would be a second possible 'veto'.

It therefore appears obvious that there is no legal way of getting round this accession process, no matter how much 'flexibility and pragmatism' one wished the European Union to show. ${ }^{100}$ Legal lucubration based on embellishments-starting with the so-called internal enlargement theory, or the link derived from European citizenship, that some attempt to argue as grounds for Catalonia remaining in the Union-has no place in the framework of EU law.

there to be 'a serious and persistent breach by a Member State of the values referred to in Article 2 [TEU]', to wit: human dignity, freedom, democracy, equality, the rule of law and respect for human rights.

${ }_{98}$ Although it refers to the plans for a Treaty establishing a Constitution for Europe, on which the Lisbon Treaty was based (Articles I-58, III-325.3 and IV-446), see M. Urrea Corres, 'La retirada de Estados de la Unión Europea en la Constitución Europea', La constitucionalización del proceso de integración europea, VVAA (Madrid: Escuela Diplomática, 2005), pp. 289-304. See also R.J. Triel, 'Providing a constitutional framework for withdrawal from the EU: Article 59 of the draft European constitution', International and Comparative Law Quarterly, 53 (2004), pp. 407-428; ibid, 'Secession from the European Union; Checking Out of the Proverbial "Cockroach Motel”, Fordham International Law Journal, 2 (2004), pp. 590-64I; J.-V Louis, 'Union membership: accession, suspension of membership rights and unilateral withdrawal. Some reflections', in A Constitution for Europe: The IGC, the Ratification Process and Beyond, ed. by I. Pernice and J. Zemánek (Baden-Baden: Nomos, 2005); ibid, 'Le droit de retrait de l'Union européenne', Cabiers de Droit Européen (2006), pp. 293314; Th. Bruha and C. Nowak, 'Recht auf Austritt aus der Europäischen Unión?', Archiv des Völkerrechts (2004), pp. I-25; L. Grosclaude, 'La clause de retrait du Traité établissant une Constitution pour l'Europe réflexions sur un possible marché de dupes', Revue Trimestrielle de Droit Européen, 2 (2005), pp. 533-548.

99 The planned road map can be consulted in the white paper entitled Libro Blanco - La transición nacional de Cataluña, particularly pp. II5-I23 (on 'ways of integration of Catalonia into the European Union').

Ioo These are two of the core arguments supporting the position set forth in the white paper; ibid., p. II9. 
(3) The legal inconsistency of the internal enlargement theory:

The false use of European citizenship as a link connecting the new (Catalan) State to the European

Union

Indeed, there are authors who defend what could be called the internal enlargement theory. ${ }^{\text {Ior }}$ Under this theory, on the basis of the democratic principle that inspires the European Union (Article 2 TEU), the citizens of a hypothetical successor State could keep hold of their European citizenship (Articles 20 to 25 TFEU) and, therefore, remain fully within the Union. ${ }^{102}$ In fact, this is the position that has been adopted by the National Transition Advisory Board (a think tank set up to advise on the different ramifications of the independence process) in its 2014 report on the ways in which an independent Catalonia could be allowed to remain in the Union. ${ }^{103}$

Resorting to this theory - somewhat simplistic, if one may take the liberty, in its legal reasoning ${ }^{104}$ - to support the consideration of the new State as a member of the European Union is, in this author's opinion, entirely unsustainable, and this is also the opinion of a majority of the EU law community ${ }^{\mathrm{ros}}$ and the institutions of the Union themselves. ${ }^{106}$ This theory is a self-serving legal construction that appears ignorant of the basic fact that European citizenship is not a citizenship of origin, but rather something derived from holding the citizenship of a Member State: 'every person holding the nationality of a Member State shall be a citizen of the Union' (Article 20.I TFEU). In other words, one is a European citizen - and therefore subject to the rights and duties derived from this status (Articles 20 to 25 TFEU) - as a result of holding the citizenship of a Member State. Ergo, if Catalonia were to break away from Spain and found an independent - and therefore non-EU-

го See for example J. Matas Dalmases, L'ampliació interna de la Unió Europea (Barcelona, 20ro); J. Ridao Martín and A. González Bondía, op. cit. ('La Unión Europea ante...), note 96; X. Sala i Martín, És l'Hora dels Adéus (Barcelona: Rosa del Vents, 20I4) (also available in Spanish, http://salaimartin.com), particularly the section entitled 'Dentro de Europa'. A very similar position is also reflected in the institutional papers cited above.

Ior Obviously, as has already been stated, the legal situation would change considerably if an agreement were reached between the successor State and the State from which it had broken away, and presented to the European Union by the two States together.

ro3 Report number 6, 'Les vies d'integració de Catalunya a la Unió Europea' (Barcelona: Generalitat de Catalunya, 20I4).

${ }^{104}$ In his interesting monographic study on this issue, Manuel Medina Ortega goes one step further, arguing that the stance adopted by those who defend the theory whereby secession would be followed by automatically remaining in the EU 'displays a certain ignorance of the nature of the European Union' and 'a high degree of arbitrariness and amateurism'; $\mathrm{El}$ derecho de secesión en la Unión Europea, (Madrid: Marcial Pons, 2014), particularly pp. 199-200.

ros One example can be seen the well-founded work of M. Campins Eritja op. cit. ('The European Union...'), note 95. Likewise, E. Linde Paniagua, 'Estado versus Nación. En el fin de la era de los nacionalismos en Europa', Revista de Derecho de la Unión Europea, 25 (2003), pp. 2I-45; ibid., op. cit. ('Contestación al trabajo de Ridao-González...'), note 96; D. López Garrido, (ed.), F. Aldecoa Luzarraga and G. Cámara, Cataluña ante la Unión Europea. Las consecuencias jurídicas de la independencia (Madrid: Fundación Alternativas, 2015), particularly pp. I8-20; A. Mangas Martín, 'La secesión de territorios en un Estado miembro: efectos en el Derecho de la Unión Europea', Revista de Derecho de la Unión Europea, 25 (2013), pp. 4767; M. Medina Ortega, op. cit. (El derecho de secesión...),note Io4; ibid, 'Los ciudadanos europeos y la secesión de territorios en la Unión Europea', Revista de Derecho de la Unión Europea, 25 (2013), pp. 69-86; I. Molina, 'Independentismo e integración europea: la imposible adhesión automática a la UE dentro de un territorio secesionado', Real Instituto ElcanoARI, 80 (22 November 2012).

${ }^{106}$ Perhaps, as an argument of weight regarding the European Union's legal position on this issue we could cite the clear and emphatic position expounded by Jean-Claude Piris, who was head of the Council's Legal Service, for many years: 'Cataluña y la Union Europea', El País, 29 August 2015 (also available in English, 'Catalonia and the European Union'). In his view, 'that those who hold that the European Union would accept a purportedly independent Catalonia into its fold are demonstrating their ignorance of both applicable legislation and of the political realities in the EU's member states'. 
State, its 'nationals' would hold a new citizenship and therefore, except in cases of voluntary dual citizenship, ${ }^{107}$ they would not hold the citizenship of any Member State of the Union and would not be EU citizens. ${ }^{108}$ And, of course, if the hypothetical new State were to resort to the constitutional legislation of the State from which it had just separated in an attempt to keep hold of the former citizenship (as well as the new Catalan citizenship) and thus preserve the link to European citizenship, EU law provides, in this author's understanding, sufficient means to prevent this, both on the basis of the Court of Justice of the European Union (CJEU)'s case law ${ }^{109}$ and in the terms laid down by the Member States themselves. ${ }^{\text {IIO }}$

For further clarification, although this is entirely redundant, the founding treaties insist both on the basic idea that 'citizenship of the Union shall be additional to and not replace national citizenship' (Article 20.I TFEU), and that the rights inherent to this European citizenship 'shall be exercised in accordance with the conditions and limits defined by the Treaties and by the measures adopted thereunder' (Article 20.2 TFEU). And, in this regard, it is not necessary to insist yet again on the clear link between all the norms applicable to the territory of the States Parties to the founding treaties.

It comes as no surprise that this interpretation matches the stance adopted by the two institutions that best represent the European Union's supranational community aspect - European Commission (political sphere) - and case law aspect - CJEU (legal sphere) - institutions that are, respectively, the 'guardian of the Treaties' (Article 17 TEU and Articles 244 to 250 TFEU) and the upholder of compliance with EU law (Article is TEU and Articles 25I to 28I TFEU).

The European Commission, in response to the European Citizens' Initiative petitioning for a 'guarantee that the citizens of a new State resulting from the secession of one part of an EU Member State would continue to be citizens of the Union', stated in no uncertain terms that, 'pursuant to Article 20 of the TFEU, only persons who have the citizenship of a Member State are EU citizens', adding that 'in the event of the secession of one part of a Member State, the solution would have to be

107 See III.4 above.

ro8 Now is not the time to delve into the complex issue of citizenship, which has not, of course, escaped the attentions of the National Transition Council; see report to on the constitution-making process, pp. 28-32 (on 'provisional citizenship arrangements').

Io9 Although this is not an exhaustive list, two possible ways should be noted. Firstly, settled CJEU case law indicates that preventing evasion and abuse of the law is a general principle of EU law, and 'Community law cannot be relied on for abusive or fraudulent ends'; judgment of 2I February 2006, Halifax and others, C-255/02, ECR I-609, paragraph 68; judgment of 20 September 2007, Tum and Dari, C-16/05, ECR I-7415, paragraph 64; judgment of 21 July 20II, Tural Oguz, C-186/ro, ECR I-6957). It is noteworthy that the CJEU's own definition of abusive practice refers to the existence of 'a subjective element consisting in the intention to obtain an advantage from the Community rules by creating artificially the conditions laid down for obtaining it', judgment of I4 December 2000, Emsland-Stärke, C-94/05, ECR I-26i9), paragraphs 52 and 53; judgment of 2I July 2005, Eichsfelder Schlachtbetrieb, C-515/03, ECR I-7355, paragraph 39; judgment of 16 October 2012 , Hungary $v$ Slovak Republic, C-364/IO, paragraph 58.

ro Under the Declaration to the Treaty on European Union (adopted at Maastricht and signed by all Member States) on Nationality of a Member State, 'Member States may declare, for information, who are to be considered their nationals for Community purposes by way of a declaration lodged with the Presidency'. The United Kingdom made use of this provision to issue a Declaration on its nationals. 
found and negotiated within the legal international system'. ${ }^{\text {III }}$ The President of the Commission himself later made the link between European citizenship and the citizenship of a Member State unambiguously clear, clarifying that the former does not, in any way, replace the latter. ${ }^{\mathrm{II}}$ President Juncker has echoed this position. ${ }^{\mathrm{II}}$

But, as for the matter of most interest to a legal analysis such as this one, CJEU case law fully supports these arguments, leaving no room for doubt regarding the indisputable fact that European citizenship exists as a direct consequence of holding the citizenship of an EU Member State. ${ }^{\mathrm{II}}$ Thus, if that citizenship is lost, the link to European citizenship is lost. Moreover, the CJEU has gone so far as to assert clearly that Spain is the unitary subject of EU, regardless of its internal structure. ${ }^{\mathrm{II}}$

In short, whether or not a unilateral declaration of independence takes place, the unitary subject of public international law is Spain and Spain alone, and in the hypothetical case of Catalonia becoming independent, it would be left out of the European Union ${ }^{116}$ and, in any case, considered a third State which, in order to join the Union, would have to follow the process established ad boc in Article 49 TEU.

(4) Added legal inconsistency of the allegedly automatic nature of internal enlargement: The requirement to follow the procedure under Article 49 TEU

If it is tenuous to sustain the possibility of a supposed internal enlargement as the result of the application of the principle of democracy - since this would violate the concept of European citizenship and the status of the Member States as the sole subjects of international law in the European Union's eyes - it is even more tenuous to assume that, on top of this, this would happen

III Response to a question posed to the Commission in relation to a citizens' initiative on 'Strengthening civic participation in the taking of decisions on collective sovereignty', C (2012) 3689 final, 30 May 2012.

II2 Response by Commission President Durão Barroso on 28 August 2012 to the question posed by Mara Bizzoto; Doc. E-007453/2012: 'The Commission confirms that (...) EU citizenship is additional to and does not replace national citizenship (that is, the citizenship of an EU Member State). It also confirms that, in the hypothetical event of a secession of a part of an EU Member State, the solution would have to be found and negotiated within the international legal order. Any other consideration related to the consequences of such event would be of a conjectural nature.'

I13 Answer given by President Juncker on behalf of the Commission, E-or1776/2015, of 21 September 2015.

${ }^{114}$ CJEU judgment of 20 February 200I, The Queen $v$ Secretary of State for the Home Department, ex parte: Manjit Kaur, C-192/99, ECR I-I237, paragraph 25; judgment of I2 September 2006, Spain v United Kingdom, C-I45/04, ECR I-796I, particularly paragraph 78; judgment of I2 September 2006, M.C.G. Eman and O. B. Sevinger, C-300/04, ECR I-8055, particularly paragraph 6I; judgment of 2 March 20I0, Rottmann, C-I35/08, ECR I-I449, particularly paragraphs 54-58.

is CJEU judgment of 29 November 2007, Rafael de Bustamante Tello, C-Io/06 ECR I-IO38I, which specifically establishes that 'even if the distribution of responsibilities at intra-State level varies according to the institutional make-up of each State, that State must be considered to be a unitary subject of public international law' (paragraph 39).

"I6 Obviously it would also be left out of the European Central Bank, the Eurogroup and the single currency; in this regard see D. López Garrido (ed.), F. Aldecoa Luzarraga and G. Cámara, op. cit. (Cataluña ante la Unión Europea), note io5, pp. 15-17. Arguments for the opposite view-although they are, in this author's understanding, legally unfounded-can be found in X. Salas i Martín, op. cit. (¿La hora del Adios?). Certainly, nothing would prevent a hypothetical independent Catalonia from using the euro as its own currency - just as nothing prevents Ecuador from using the dollar- but this would not in any way mean participating in the Eurozone institutions, not even access to financing from the European Central Bank; see J. Borrell and J. Llorach, Las cuentas y los cuentos de la independencia, (Madrid: Catarata, 2015), particularly pp. I48-150, which dismantles the theory that the subsidiaries of banks of a third State, which is what an independent Catalonia would be, would have access to credit from the European Central Bank. Access to credit would indeed be available, as it is to the EU-based subsidiaries of any other bank of a third State, but 'only in proportion to the subsidiary's assets, and assets worth over $100 \%$ of the loan value would have to be pledged as collateral' (p. I48). 
automatically. Such a stance is not only contrary to EU law; it also displays an ignorance of the most basic procedural requirements of international law. Firstly, without an agreement between the successor State and Spain, it is difficult to imagine any possible agreement with the European Union. And, even in the hypothetical case of such an agreement being reached - more than unlikely in the scenario we are discussing here - in any case a (very long) negotiation process would have to begin, and, for the Union to be enlarged to include the new State, the conditions set forth in Article 49 TEU (i.e., consultation of the Commission, consent of the European Parliament, subsequent negotiation of an accession agreement and final ratification of this by all the Member States) would have to be met in full. Therefore, proposing that the new State should accede immediately and automatically is pure wishful thinking.

Moreover, the new withdrawal procedure introduced by the Lisbon Treaty makes it clear that if, following a withdrawal, the same State wished to re-join the Union, its request shall be subject to the procedure referred to in Article 49' (Article 50.5 TEU). Therefore, a State that withdraws from the EU neither maintains a kind of 'preferential joining right' nor enjoys any 'easing' of the path to accession, and therefore has to undergo the general process under Article 49, just like any other candidate. As Mar Campins has recently put it so well, if this is the case for an EU Member State that has been a part of the EU, it must also be so for a part of the territory of a EU Member State that decides to separate in order to create a new State'. ${ }^{117}$ Therefore, the most that a hypothetical independent Catalonia could aspire to would be consideration as a third party, bearing in mind that, as we have already seen, from the perspective of international law it would not meet the requirement of being a State, either.

\section{CLOSING REMARKS: THE NEED TO BRING THE POLITICAL DEBATE ON INDEPENDENCE}

\section{BACK TO THE RIGHT LEGAL CONTEXT}

Catalonia cannot in any way be considered a subject in its own right with a purported 'right to decide' which, in the event of a hypothetical materialisation of the goals of the Resolution of the Catalan Parliament of 2 December 2015, would then have the authority to pass a unilateral declaration of independence which, in turn, would trigger a process leading to the formation of its own State. And this cannot be so either on a domestic level or on an international one. Both the Spanish Constitution and international law directly oppose any type of secession by part of a territory of a State that, as is the case with Spain, is founded on the principles of democracy and the rule of law.

Moreover, international law clearly establishes the validity of the principle of territorial integrity, as well as the obvious inapplicability of the self-determination principle to a context like that of Catalonia; such an idea would, therefore, contravene the most basic postulations of international law on the subject. On top of that, all the States of the international community have a duty to, in the words of the United Nations General Assembly, 'desist and refrain from actions aimed at the partial or total disruption of the national unity and territorial integrity' of States in which part of the

\footnotetext{
${ }^{117}$ Op. cit. ('The European Union...'), note 95, p. 479.
} 
territory has made a unilateral declaration of independence in breach of the law. From this we can infer that States have a kind of duty to refrain from recognizing the aspiring State resulting from a unilateral declaration of this kind, as to do otherwise could be even interpreted as meddling in Spain's internal affairs. Moreover, in the event that, despite all that has been said above, part of Spain's territory were to persist in performing unequivocal acts seeking its independence, it appears beyond all legal doubt that the nascent State - in the unlikely event that it managed to be considered as a State- would be left out of all the international organizations of which Spain is a member, including, of course, the European Union. And this is quite aside from the fact that the immense majority of the international treaties to which Spain is currently party would also cease to apply in that part of its territory.

Indeed, within the scope of the European Union it is difficult to consider the hypothetical scenario of an independent Catalonia, since the EU is a 'Union of States' (Article I TEU) of which Spain is a Member State (Article $52 \mathrm{TEU}$ ) and which has a duty to respect the national identities of its Member States and ensure their territorial integrity (Article 4.2 TEU). However, if this hypothesis of independence were to materialize, the resulting State would, to all intents and purposes, be considered a third State which, in order to join the European Union, would have to undergo the procedure set forth ad boc in Article 49 TEU.

Quite another matter is clarifying whether, on a political level, setting aside the legal considerations made in this paper and assuming the continuation of constitutional legality, attempts could be made to find Catalonia a new constitutional 'fit' within Spain that respected territorial unity and were reasonably satisfactory to all involved. As the Spanish Constitutional Court said in its already mentioned judgment of 2 December 2015, "the Constitution doesn't claim that its provisions are set in stone". ${ }^{118}$ It goes without saying, however, that this approach to the 'Catalan question' is a different matter altogether, and the present, strictly legal discussion of the challenge implicit in the current activity of the Catalan Parliament is not the place for such an analysis.

II8 It is quite the opposite. The Spanish Constitutional Court clarifies that "the Constitution is not an intangible or unchangeable legal text (...). The Constitution is entirely open to formal revision, which can be requested or proposed by, among other authorities of the State, the assemblies of the Autonomous Communities (...). There is room in our system for ideas to be put forward that seek to modify the foundations of our constitutional order, provided that this is not prepared or defended by way of an activity that violates the principles of democracy, fundamental rights or any other constitutional mandates, and provided that the attempt to achieve this is made through the established constitutional reform procedures"; CC judgment 259/2015, loc. cit., note 5 in fine, Legal Grounds section, paragraph 7. 